\title{
Influence of future climate and cropland expansion on isoprene emissions and tropospheric ozone
}

\author{
O. J. Squire ${ }^{1}$, A. T. Archibald ${ }^{1,2}$, N. L. Abraham ${ }^{1,2}$, D. J. Beerling ${ }^{3}$, C. N. Hewitt ${ }^{4}$, J. Lathière ${ }^{3,4, *}$, R. C. Pike ${ }^{1, * *}$, \\ P. J. Telford ${ }^{1,2}$, and J. A. Pyle ${ }^{1,2}$ \\ ${ }^{1}$ Centre for Atmospheric Science, Department of Chemistry, University of Cambridge, Cambridge, CB2 1EW, UK \\ ${ }^{2}$ National Centre for Atmospheric Science, Department of Chemistry, University of Cambridge, Cambridge, CB2 1EW, UK \\ ${ }^{3}$ Department of Animal and Plant Sciences, University of Sheffield, Sheffield, S10 2TN, UK \\ ${ }^{4}$ Lancaster Environment Centre, Lancaster University, Lancaster, LA1 4YQ, UK \\ *now at: Laboratoire des Sciences du Climat et de l'Environnement, IPSL, UVSQ, CEA, CNRS, Gif-sur-Yvette, France \\ **now at: Draper Fisher Jurvetson, 2882 Sand Hill Road, Suite 150 Menlo Park, CA 94025, USA
}

Correspondence to: O. J. Squire (ojsquire@ gmail.com)

Received: 29 May 2013 - Published in Atmos. Chem. Phys. Discuss.: 9 July 2013

Revised: 19 December 2013 - Accepted: 19 December 2013 - Published: 28 January 2014

\begin{abstract}
Over the 21st century, changes in $\mathrm{CO}_{2}$ levels, climate and land use are expected to alter the global distribution of vegetation, leading to changes in trace gas emissions from plants, including, importantly, the emissions of isoprene. This, combined with changes in anthropogenic emissions, has the potential to impact tropospheric ozone levels, which above a certain level are harmful to animals and vegetation. In this study we use a biogenic emissions model following the empirical parameterisation of the MEGAN model, with vegetation distributions calculated by the Sheffield Dynamic Global Vegetation Model (SDGVM) to explore a range of potential future (2095) changes in isoprene emissions caused by changes in climate (including natural land use changes), land use, and the inhibition of isoprene emissions by $\mathrm{CO}_{2}$. From the present-day (2000) value of $467 \mathrm{Tg} \mathrm{Cyr}^{-1}$, we find that the combined impact of these factors could cause a net decrease in isoprene emissions of $259 \mathrm{Tg} \mathrm{C} \mathrm{yr}^{-1}(55 \%)$ with individual contributions of $+78 \mathrm{Tg} \mathrm{Cyr}^{-1}$ (climate change), $-190 \mathrm{Tg} \mathrm{C} \mathrm{yr}^{-1}$ (land use) and $-147 \mathrm{Tg} \mathrm{C} \mathrm{yr}^{-1}\left(\mathrm{CO}_{2}\right.$ inhibition). Using these isoprene emissions and changes in anthropogenic emissions, a series of integrations is conducted with the UM-UKCA chemistry-climate model with the aim of examining changes in ozone over the 21 st century. Globally, all combined future changes cause a decrease in the tropospheric ozone burden of $27 \mathrm{Tg}(7 \%)$ from $379 \mathrm{Tg}$ in the present-day. At the surface, decreases in ozone of $6-10 \mathrm{ppb}$ are calculated over the oceans and developed northern hemispheric regions, due to reduced $\mathrm{NO}_{\mathrm{x}}$ transport by PAN and reduc-
\end{abstract}

tions in $\mathrm{NO}_{\mathrm{x}}$ emissions in these areas respectively. Increases of 4-6 ppb are calculated in the continental tropics due to cropland expansion in these regions, increased $\mathrm{CO}_{2}$ inhibition of isoprene emissions, and higher temperatures due to climate change. These effects outweigh the decreases in tropical ozone caused by increased tropical isoprene emissions with climate change. Our land use change scenario consists of cropland expansion, which is most pronounced in the tropics. The tropics are also where land use change causes the greatest increases in ozone. As such there is potential for increased crop exposure to harmful levels of ozone. However, we find that these ozone increases are still not large enough to raise ozone to such damaging levels.

\section{Introduction}

Plants emit biogenic volatile organic compounds (BVOCs) into the Earth's atmosphere, with the largest fluxes being for isoprene (2-methyl-1,3-butadiene), with annual emissions of $\sim 500 \mathrm{TgC}$ (Guenther et al., 2006). This value is greater than the total amount of non-methane hydrocarbons released annually due to anthropogenic activities. However, not all plants emit isoprene, and those that do, emit it in very different amounts. For example, broad-leaved rainforest has been measured to emit $\sim 2.5 \mathrm{mg} \mathrm{m}^{-2} \mathrm{~h}^{-1}$ (Rinne et al., 2002; Misztal et al., 2011), whilst crops such as maize and sugarcane are thought to emit much less isoprene $\left(\sim 0.09 \mathrm{mg} \mathrm{m}^{-2} \mathrm{~h}^{-1}\right.$, 
Guenther et al., 2006). On the other hand, much greater isoprene fluxes of up to $13.0 \mathrm{mg} \mathrm{m}^{-2} \mathrm{~h}^{-1}$ have been measured from fast-growing plants such as oil palm (Misztal et al., 2011). Isoprene is a very reactive VOC that is readily oxidised in the atmosphere, and in the presence of oxides of nitrogen $\left(\mathrm{NO}_{\mathrm{x}}=\mathrm{NO}+\mathrm{NO}_{2}\right)$, it can lead to the formation of ozone $\left(\mathrm{O}_{3}\right)$ (e.g. Chameides et al., 1988). However the chemical relationship between VOCs, $\mathrm{NO}_{\mathrm{x}}$ and $\mathrm{O}_{3}$ is nonlinear; the response of $\mathrm{O}_{3}$ to changes in either precursor gas depends on their ratio (see the Empirical Kinetics Modeling Approach diagrams in, e.g. Dodge, 1977; Sillman and He, 2002). In sufficient quantities, $\mathrm{O}_{3}$ is recognised to be damaging to both humans and plants (WHO, 2000), and has been shown to lead to substantial losses in global crop yields (Avnery et al., 2011a). As isoprene is a precursor to $\mathrm{O}_{3}$ formation, changes to factors that influence isoprene emissions have the potential to alter the degree of $\mathrm{O}_{3}$ damage to the biosphere.

There are several factors that can affect isoprene emissions. From a fixed vegetation distribution, isoprene emissions are directly stimulated by increases in temperature following an Arrhenius-like relationship (Tingey et al., 1979), and are directly inhibited under elevated concentrations of $\mathrm{CO}_{2}$ (Rosenstiel et al., 2003). However, increased $\mathrm{CO}_{2}$ levels may also lead indirectly to greater isoprene emissions by extended fertilisation of the biosphere (e.g. Tao and Jain, 2005; Arneth et al., 2007). Similarly, increases in temperature may indirectly decrease isoprene emissions by decreasing soil moisture, thus leading to "die-back" of isopreneemitting vegetation (Cox et al., 2000, 2004; Sanderson et al., 2003). Changes in land use that affect the extent and distribution of vegetation also have the potential to alter isoprene emissions. Anthropogenic land use change, on the global scale, contributes a net decrease to isoprene emissions as generally this involves replacement of high isoprene emitters with lower ones (e.g. Tao and Jain, 2005; Lathière et al., 2005; Wu et al., 2012). However, this is not always the case, especially on the regional scale where some land use scenarios show increased isoprene emissions. Examples are the replacement of broad-leaved rainforest with oil palm (Hewitt et al., 2009; Ashworth et al., 2012; Warwick et al., 2013) or agricultural cropland with Arundo donax for biofuel production (Porter et al., 2012). In the current study we do not include such land use changes.

There is a fine balance between those factors that increase isoprene emissions (direct effects of temperature, $\mathrm{CO}_{2}$ fertilisation), and those that decrease them (die-back, $\mathrm{CO}_{2}$ inhibition, land use change). This balance may well change over the next century. Rising $\mathrm{CO}_{2}$ levels are expected to cause rises in temperature and $\mathrm{CO}_{2}$ fertilisation, which would lead to isoprene emission increases. Some studies calculate that these increases would be more than compensated for by increases in $\mathrm{CO}_{2}$ inhibition (Heald et al., 2009; Young et al., 2009; Pacifico et al., 2012) and anthropogenic land use change (Ganzeveld et al., 2010; Wu et al., 2012). However the magnitude of these terms and the degree to which they compensate each other is scenario dependent and still remains highly uncertain.

Due to the non-linearity of VOC- $\mathrm{NO}_{\mathrm{x}}-\mathrm{O}_{3}$ chemistry, the $\mathrm{O}_{3}$ response to these isoprene emission changes depends on whether the environment is $\mathrm{NO}_{\mathrm{x}}$-limited or VOC-limited (Wiedinmyer et al., 2006; Zeng et al., 2008; Young et al., 2009; Wu et al., 2012; Pacifico et al., 2012). When sufficient $\mathrm{NO}_{\mathrm{x}}$ is available, isoprene reacts with $\mathrm{OH}$ and molecular oxygen to produce hydroxyperoxy radicals, which convert $\mathrm{NO}$ to $\mathrm{NO}_{2}$, leading to $\mathrm{O}_{3}$ formation. In low $\mathrm{NO}_{\mathrm{x}}$, VOCrich environments, the rate of this $\mathrm{NO}_{\mathrm{x}}$-dependent pathway decreases, and it becomes more favourable for isoprene to be oxidised directly by $\mathrm{O}_{3}$, leading to $\mathrm{O}_{3}$ removal. $\mathrm{O}_{3}$ production is further limited by the removal of $\mathrm{NO}_{\mathrm{x}}$ as isoprene hydroxyperoxy radicals react with $\mathrm{NO}$ to form isoprene nitrates. The degree to which $\mathrm{NO}_{\mathrm{x}}$ is regenerated from isoprene nitrate degradation remains uncertain (Fiore et al., 2012), and has a significant effect on the $\mathrm{O}_{3}$ response to isoprene emission changes (von Kuhlmann et al., 2004; Wu et al., 2007; Horowitz et al., 2007).

The first aim of this current study is to explore how contributions from the main factors that affect tropospheric $\mathrm{O}_{3}$ could change over the 21 st century. This is achieved by use of a global chemistry-climate model (the UK MetOffice Unified Model coupled to the UK Chemistry and Aerosol model (UM-UKCA)) as detailed in Sect. 2. One of the factors investigated is changes in isoprene emissions, and in this section we also outline the method used for calculating these isoprene emission changes. In Sect. 3 the generated isoprene emissions are analysed to show how they could change over the 21 st century due to changes in climate, land use and $\mathrm{CO}_{2}$ inhibition. In Sect. 4 we use the results of the UM-UKCA integrations to attribute future $\mathrm{O}_{3}$ changes to changes in climate, isoprene emissions with climate, anthropogenic emissions, land use and $\mathrm{CO}_{2}$ inhibition of isoprene emissions.

The second aim of this study is to determine whether changes in isoprene emissions due to anthropogenic land use (simulated here as cropland expansion) could cause increased exposure of those crops to harmful levels of $\mathrm{O}_{3}$. This is addressed in Sect. 5 by calculating the effect of cropland expansion on the "Accumulated exposure $\left(\right.$ to $\left._{3}\right)$ Over a Threshold of $40 \mathrm{ppb}$ " (AOT40) diagnostic. The AOT40 is recommended by the World Health Organization (WHO, 2000) as a diagnostic for quantifying harmful $\mathrm{O}_{3}$ exposure to vegetation. The effects of changes in $\mathrm{O}_{3}$ on crop damage have been examined in several previous studies (e.g. Ashmore, 2005; Van Dingenen et al., 2009; Fuhrer, 2009; Avnery et al., 2011b), however very few studies consider specifically the contribution from isoprene emission changes (Ashworth et al., 2012, 2013), which is the focus here.

Isoprene oxidation chemistry is too complex to include explicitly in a global model, so the chemistry must be parameterised. This introduces uncertainties, which we investigate in a companion paper (Squire et al., 2014) by comparing four different isoprene chemical schemes, all of which are 
currently used in Earth System Models. One notable source of uncertainty is the degree to which $\mathrm{HO}_{\mathrm{x}}$ is regenerated from isoprene degradation under low $\mathrm{NO}_{\mathrm{x}}$ conditions. Recent studies have demonstrated biases between measured and modelled $\mathrm{HO}_{2}$ (Fuchs et al., 2011) and $\mathrm{OH}$ (Mao et al., 2012) under high VOC (low $\mathrm{NO}_{\mathrm{x}}$ ) conditions. Proposals have been put forward for missing mechanistic pathways (e.g. Paulot et al., 2009; Peeters et al., 2009) that to some extent reconcile these discrepancies (Archibald et al., 2010). In the companion paper we investigate the sensitivity of our results to including these new pathways.

\section{Model and Experiment}

In order to establish how contributions from the main factors that affect tropospheric $\mathrm{O}_{3}$ could change over the 21st century, a present-day (2000) integration and a range of future (2095) integrations were conducted with UM-UKCA as detailed in Sect. 2.3. For all integrations isoprene emissions were first calculated offline using a dynamic global vegetation model and a biogenic emissions model as described in Sect. 2.1. Additionally, to investigate the effect of changes in land use the distribution of land surface types in UM-UKCA had to be altered, and this process is described in Sect. 2.2.

\subsection{Isoprene emission calculations}

Isoprene emissions were calculated under present-day (2000) conditions and for a series of future (2095) conditions. In Sect. 3 differences in these emissions are analysed to ascertain individual contributions to future isoprene emission changes from future changes in climate, land use, $\mathrm{CO}_{2}$ inhibition of isoprene emissions and the combined effect of all of these factors. In all cases first the vegetation distribution was determined using the Sheffield Dynamic Global Vegetation Model (SDGVM) (Beerling et al., 1997; Beerling and Woodward, 2001). The model was run in time slices, for presentday (2000) and future (2095) conditions, each time being run to vegetative equilibrium. The SDGVM calculates the potential distribution and leaf area index of six plant functional types (PFTs): $\mathrm{C}_{3}$ and $\mathrm{C}_{4}$ grasses, evergreen broad-leaved and needle-leaved trees, and deciduous broad-leaved and needleleaved trees (Lathière et al., 2010). The SDGVM was driven by climate conditions generated with the HadGEM1 model (Johns et al., 1997). For calculation of the future isoprene emissions the SRES B2 climate scenario was used (Riahi et al., 2007). The vegetation distribution from the SDGVM was then used as input for a biogenic emissions model based on MEGAN (Guenther et al., 2006), as described in Lathière et al. (2010), which produced the isoprene emissions. Additionally, when future $\mathrm{CO}_{2}$ inhibition of isoprene emissions was included, the parameterisation of Possell et al. (2005) was used in the biogenic emissions model, as in Lathière et al. (2010).

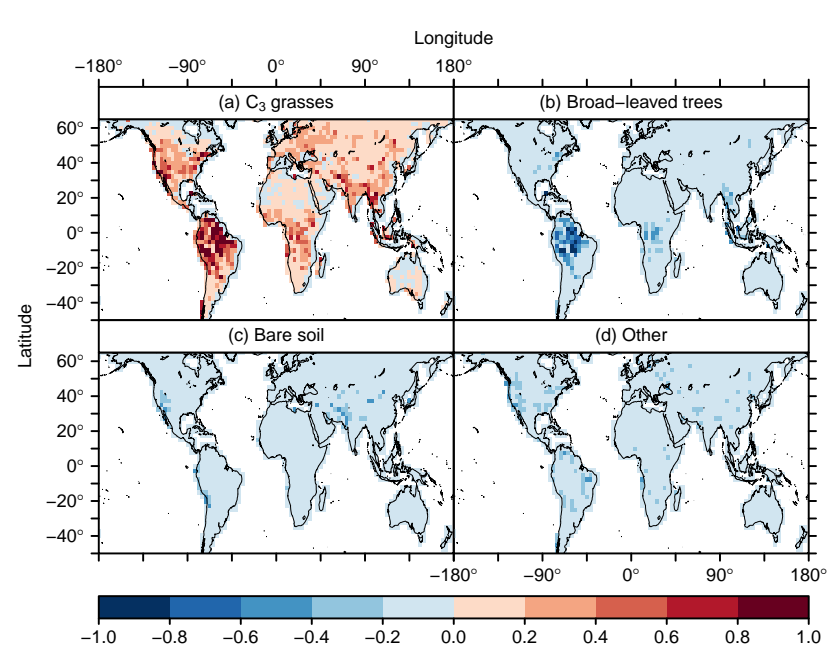

Fig. 1. Change in grid cell fraction of UM-UKCA land surface types between present-day (2000) and the anthropogenic land use scenario (cropland expansion) for 2095 (2095-2000). Changes in the crop fraction (assigned to $\mathrm{C}_{3}$ grasses) were calculated using the IMAGE 2.1 model (Alcamo, 1999).

\subsection{Land surface changes}

As the SDGVM does not explicitly calculate the distribution of crops, for the inclusion of future cropland expansion the IMAGE 2.1 model (Alcamo, 1999) was used to generate a crop map in line with the A1B SRES scenario (Nakicenovic et al., 2000). This crop map was then combined with the natural vegetation distribution from the SDGVM to create a new distribution of PFTs and leaf area index, and this was used as input for the biogenic emissions model that gave the altered isoprene emissions. The new PFT distribution and leaf area index was also used in those UM-UKCA integrations that included future cropland expansion, as the PFT affects a number of model surface properties such as the chemical deposition velocity and surface roughness. In UM-UKCA there are nine land surface types (LSTs): broad-leaved trees, needle-leaved trees, $\mathrm{C}_{3}$ grasses, $\mathrm{C}_{4}$ grasses, shrubs, bare soil, urban, ice and inland water. These LSTs do not correspond exactly to the PFTs calculated by the SDGVM, and as such in the land use change integrations the SDGVM PFTs had to be mapped onto the UM-UKCA LSTs. As $\mathrm{C}_{3}$ and $\mathrm{C}_{4}$ grasses exist in both models their distributions in UMUKCA followed that of the SDGVM, with the addition that all crops were also assigned to $\mathrm{C}_{3}$ grasses. This simplification could be made as in UM-UKCA the deposition properties of both grass types are identical and there are only small differences in other surface properties including aerodynamic resistance. Both broad-leaved and needle-leaved categories in the SDGVM were mapped to broad-leaved and needleleaved trees respectively in UM-UKCA. Figure 1 shows the difference in the grid cell fraction of UM-UKCA LSTs between 2000 and 2095 for the land use change scenario. The 
Table 1. Model integrations conducted with UM-UKCA (BASE and Runs 1-6). PD= present-day (2000), Fut=Future (2095). The lower section of the table indicates how changes due to each perturbation are calculated.

\begin{tabular}{lccccc}
\hline $\begin{array}{l}\text { UM-UKCA } \\
\text { integration }\end{array}$ & Climate & $\begin{array}{c}\text { Isoprene } \\
\text { emissions } \\
\text { with climate }\end{array}$ & $\begin{array}{c}\text { Anthrop- } \\
\text { ogenic } \\
\text { emissions }\end{array}$ & Land use & $\begin{array}{c}\mathrm{CO}_{2} \\
\text { inhibition }\end{array}$ \\
\hline BASE & PD & PD & PD & PD & PD \\
Run1 & Fut & PD & PD & PD & PD \\
Run2 & Fut & Fut & PD & PD & PD \\
Run3 & Fut & Fut & Fut & PD & PD \\
Run4 & Fut & Fut & Fut & Fut & PD \\
Run5 & Fut & Fut & Fut & PD & Fut \\
Run6 & Fut & Fut & Fut & Fut & Fut \\
\hline$\Delta$ Climate & $\Delta$ Isoprene & $\Delta$ Anthrop- & $\Delta$ Land use & $\Delta$ CO 2 & $\Delta$ All \\
& emissions & ogenic & & inhibition & factors \\
\hline Run1 - BASE & Run2-Run1 & Run3 - Run2 & Run4 - Run3 & Run5 - Run3 & Run6 - Run1 \\
\hline
\end{tabular}

IMAGE model calculated an increase in croplands by 2095 of $6.34 \times 10^{12} \mathrm{~m}^{2}(135 \%)$, which corresponds to an increase in the fraction of $\mathrm{C}_{3}$ grasses in UM-UKCA as shown in Fig. 1a. This expansion of crops was largely at the expense of broad-leaved trees, which show large decreases (Fig. 1b). As broad-leaved trees have a higher isoprene emission factor than crops, 12.6 and $0.09 \mathrm{mg}$ isoprene $\mathrm{m}^{-2} \mathrm{~h}^{-1}$ respectively (Guenther et al., 2006; Lathière et al., 2010), cropland expansion resulted in a decrease in isoprene emissions. The fraction of needle-leaved trees and $\mathrm{C}_{4}$ grasses also decreased (lumped into "Other"; Fig. 1d), as did those LSTs not included in the SDGVM. These LSTs were adapted from their present-day UM-UKCA values to account for cropland expansion such that in a grid cell where crops increased by a given percentage $x$, each LST was decreased by $x \%$.

\subsection{Chemistry-climate integrations}

Table 1 summarises the integrations conducted with UMUKCA. The configuration of UM-UKCA used for all integrations was the Hadley Centre Global Environment Model version 3 - Atmosphere only (HadGEM3-A r2.0) at UM version 7.3, which includes UKCA (O'Connor et al., 2013). UM-UKCA was run at a horizontal resolution of $3.75^{\circ}$ longitude $\times 2.5^{\circ}$ latitude on 60 hybrid height levels that stretch from the surface to $\sim 84 \mathrm{~km}$. The model setup is similar to that described in Telford et al. (2010), with the Chemistry of the Troposphere (CheT) chemical mechanism that consists of 56 chemical tracers, 165 photochemical reactions, dry deposition of 32 species and wet deposition of 23 species. Isoprene chemistry in CheT follows that of the Mainz Isoprene Mechanism (MIM) (Pöschl et al., 2000). The Fast-JX photolysis scheme (Neu et al., 2007) is used as implemented in Telford et al. (2013). This tropospheric version of UMUKCA employs a simplified stratospheric chemistry and, to provide a realistic upper boundary condition for the tracers, concentrations of $\mathrm{O}_{3}$ and $\mathrm{NO}_{\mathrm{y}}$ are overwritten above $30 \mathrm{hPa}$ from zonal mean values from the Cambridge 2-D model (Law and Pyle, 1993a,b) as in Telford et al. (2010). All integrations lasted five model years plus a "spin-up" period of 16 months. The present-day integration (BASE) was a year 2000 time slice and the future integrations were 2095 time slices, in which perpetual 2000 (BASE) and 2095 (future) sea surface temperatures (SSTs), sea ice concentrations (SICs) and greenhouse gases (GHGs) were used. Minimising year-toyear variability in this way ensured that differences between model integrations would be due only to the deliberate perturbation that was made (e.g. changing isoprene emissions).

In the BASE integration, mixing ratios of GHGs were $370 \mathrm{ppm}\left(\mathrm{CO}_{2}\right)$ and $1765 \mathrm{ppb}\left(\mathrm{CH}_{4}\right)$. SSTs and SICs were taken from a 1998-2002 climatology following the HadISST data set (Rayner et al., 2003). For those integrations with a 2095 climate (see Table 1), GHGs were changed to $621 \mathrm{ppm}\left(\mathrm{CO}_{2}\right)$ and $2975 \mathrm{ppb}\left(\mathrm{CH}_{4}\right)$ following the SRES B2 scenario (Riahi et al., 2007), and SSTs and SICs were taken from integrations generated by the HadGEM1 model (Stott et al., 2006) in line with the A1B SRES scenario (Nakicenovic et al., 2000).

In the present-day, anthropogenic emissions of $\mathrm{NO}_{\mathrm{x}}$, carbon monoxide, formaldehyde, ethane, propane, acetone and acetaldehyde were taken from the Edgar3.2 data set (Olivier and Berdowski, 2001). In those 2095 integrations with future anthropogenic emissions, these emissions followed the B2 + CLE scenario (Fowler et al., 2008). This scenario is an updated version of the IPCC B2 scenario (Riahi et al., 2007) to account for Current LEgislation passed in 2002 to 2006 (Dentener et al., 2005). This scenario has only small increases in emissions from emerging economies, and large emission reductions across developed countries (USA, Europe, Japan). 
We acknowledge that more than one future scenario has been followed in our experiments. However, our aim is not to produce a realistic "prediction" of future conditions, rather to investigate how $\mathrm{O}_{3}$ responds to changes in a range of parameters. As such, our aim is to explain the sensitivity of $\mathrm{O}_{3}$, and $\mathrm{O}_{3}$ feedbacks, to plausible future changes in natural and anthropogenic forcing mechanisms. The climate scenario (essentially B2) gives a climate change signal in the mid-range of the SRES scenarios. As such, we expect this to result in a moderate $\mathrm{O}_{3}$ signal. For land use change, the primary variable of interest to this work, the A1B scenario was used, which is characterised by extensive cropland expansion. The aim was to calculate a clear signal in the $\mathrm{O}_{3}$ response from land use change that involved a large change in isoprene emissions. This was paired with the B2+CLE anthropogenic emission scenario of stringent emission cuts which could be representative of a future which relies heavily on low isoprene-emitting bio-energy crops such as sugarcane or maize, as biofuel usage and emission cuts are often co-legislated.

We show later (see section 4.2 and Fig. 5) that, although the magnitude of changes in tropospheric $\mathrm{O}_{3}$ could vary with the factors investigated here, the effect of the different factors (climate, isoprene emissions, etc.) on $\mathrm{O}_{3}$ is approximately linear. So, an integration containing future climate, isoprene emissions and anthropogenic emissions produces a very similar $\mathrm{O}_{3}$ change to the sum of three separate integrations where each parameter is changed in turn. For this reason, although the use of different scenarios would likely lead to a somewhat different magnitude of future calculated $\mathrm{O}_{3}$, it is unlikely that the choice of scenario could move the model into an entirely different regime of $\mathrm{O}_{3}$ production, and with a substantially altered $\mathrm{O}_{3}$ response.

\section{Future isoprene emissions}

As discussed above, the main factors that affect isoprene emissions are changes in temperature, $\mathrm{CO}_{2}$ fertilisation, land use, and $\mathrm{CO}_{2}$ inhibition of the emissions. In this section we investigate the relative contribution of these factors to $21 \mathrm{st}$ century isoprene emission changes (Fig. 2). This is done by examining the differences between isoprene emissions calculated with the biogenic emissions model.

Figure 2a shows our present-day calculated annual average isoprene emissions. Emissions show the expected pattern of being highest around the tropics, and globally amount to $467 \mathrm{TgC}^{-1}$. This is within one standard deviation of the mean value $\left(515 \mathrm{TgC} \mathrm{Cyr}^{-1}\right)$ for a number of different model estimates as collated in Arneth et al. (2008). In Fig. 2b we see how emissions change when all future conditions are taken together. There is a global decrease of $55 \%$ to $208 \mathrm{Tg} \mathrm{Cyr}^{-1}$. In Fig. 2c-e the individual contributions to this change from climate, land use and $\mathrm{CO}_{2}$ inhibition are given.

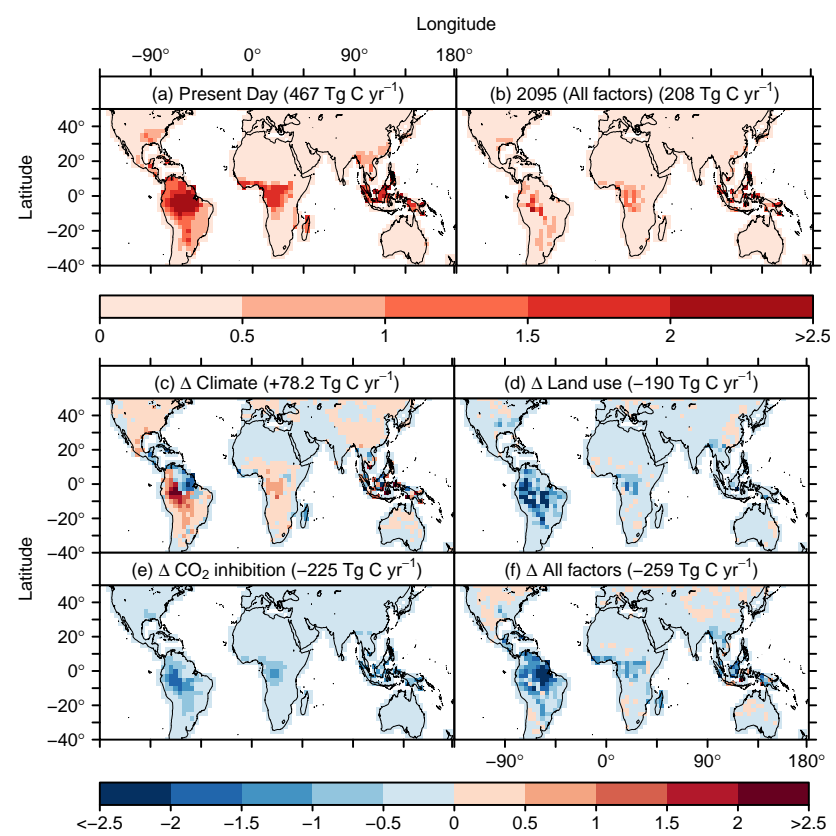

Fig. 2. Isoprene emissions $\left(\mathrm{mg} \mathrm{Cm}^{-2} \mathrm{~h}^{-1}\right)$ generated using the SDGVM and a biogenic emissions model. (a) Present-day (2000), (b) with 2095 climate, land use and $\mathrm{CO}_{2}$ inhibition, (c-e) change caused by each factor, (f) change with all factors combined. Quoted in the plot titles are total global isoprene emissions $(\mathbf{a}-\mathbf{b})$ and the change in this value (c-e).

Figure $2 \mathrm{c}$ shows the difference in isoprene emissions caused by climate change. Globally we find that climate change, which includes both changes in temperature and $\mathrm{CO}_{2}$ fertilisation, increases isoprene emissions by $78 \mathrm{TgCyr}^{-1}(17 \%)$. This increase is expected for the higher temperatures and $\mathrm{CO}_{2}$ levels in 2095, which directly stimulate isoprene emissions and extend fertilisation of the biosphere respectively. A number of studies that also include both temperature and $\mathrm{CO}_{2}$ fertilisation effects similarly calculate an increase in total global isoprene emissions with climate change over the 21st century (Sanderson et al., 2003; Lathière et al., 2005; Arneth et al., 2007; Heald et al., 2009; Young et al., 2009), but the magnitude of the increase varies considerably between studies. Four studies (this present study $\left(+17 \%,+78 \mathrm{TgC} \mathrm{Cyr}^{-1}\right)$, Sanderson et al. (2003) $\left(+21 \%,+131 \mathrm{TgCyr}^{-1}\right)$, Lathière et al. $(2005)\left(+27 \%,+136 \mathrm{TgC} \mathrm{yr}^{-1}\right)$ and $\mathrm{Wu}$ et al. (2012) $\left.\left(+25 \%,+103 \mathrm{TgC} \mathrm{yr}^{-1}\right)\right)$ calculate moderate increases. The three other studies calculate significantly higher values. The main source of discrepancy is the extent to which, in certain regions, models simulate a die-back of isoprene emitting vegetation associated with a decrease in soil moisture under the elevated temperatures of climate change. In this current study, although isoprene emissions increase overall, this dieback is calculated in areas such as the Amazon and parts of the Maritime continent. Such effects have been calculated in 
previous studies (Cox et al., 2000; Sanderson et al., 2003; Lathière et al., 2005). In some other studies 2100 soil moisture is high enough to avoid large-scale die-back, and subsequently their calculated increases in isoprene emissions are much higher (e.g. Heald et al., 2009, calculate increases of $\left.1344 \mathrm{TgC}^{-1}(265 \%)\right)$.

Figure $2 \mathrm{~d}$ shows the effect of future land use change on isoprene emissions. In those areas most affected by land use change, a decrease in isoprene emissions is calculated. This is a result of the cropland expansion scenario we employ in which broad-leaved trees are replaced with lower isoprene emitting crops. The spatial distribution of these vegetation changes is shown in Fig. 1.

Figure 1a shows the change in $\mathrm{C}_{3}$ grasses (to which crops were assigned) calculated using the IMAGE model for 2095. The main areas of cropland expansion are the Amazon, central Africa, Southeast Asia, USA, and northern Eurasia. However only the tropical regions and southeast USA show decreases in isoprene emissions. In these regions cropland expansion occurs at the expense of broad-leaved trees (Fig. 1b). Little change in isoprene emissions is calculated over the rest of the USA and northern Eurasia, as here one low isoprene emitting LST (crops) is replaced by another (largely bare soil - Fig. 1c). Wu et al. (2012) also calculate that future land use following the A1B scenario causes a decrease in end of 21st century isoprene emissions compared to the future case with present-day land use. However they calculate a smaller decrease of only $-67 \mathrm{TgC}^{-1}$ globally. The use of a different vegetation model (LPJ-DGVM) is a potential source of discrepancy.

The inhibition of isoprene emissions by $\mathrm{CO}_{2}$ (Fig. 2e) increases by 2095 due to the greater $\mathrm{CO}_{2}$ levels in the atmosphere in the B2 scenario $(+251 \mathrm{ppm},+60 \%)$. Decreases in isoprene emissions occur wherever isoprene is emitted, and are largest where emissions are highest. Globally this leads to greater decreases in isoprene emissions $\left(-225 \mathrm{Tg} \mathrm{Cyr}^{-1}\right.$, $48 \%)$ than for land use change $\left(-190 \mathrm{Tg} \mathrm{gr}^{-1}\right)$. It should be noted though that the value of $-225 \mathrm{TgCyr}^{-1}$ is calculated for the case with future climate change but not land use, i.e. under a scenario where isoprene emissions and $\mathrm{CO}_{2}$ are high. It is for this reason that the values quoted in Fig. $2 \mathrm{c}-\mathrm{e}$ do not add up to the value for the combined impact in Fig. 2f. When land use change is also taken into account, the effect of $\mathrm{CO}_{2}$ inhibition is reduced to $-147 \mathrm{TgC}^{-1}$ and the values do add up to the combined impact.

The combined effect of changes in climate, land use, and $\mathrm{CO}_{2}$ inhibition of isoprene emissions is shown in Fig. 2f. Overall there is a decrease in global isoprene emissions $\left(-259 \mathrm{TgCyr}^{-1}\right)$. Land use change $\left(-190 \mathrm{TgCyr}^{-1}\right)$ and $\mathrm{CO}_{2}$ inhibition $\left(-147 \mathrm{TgC} \mathrm{Cr}^{-1}\right)$ both contribute significantly to the net change in isoprene emissions. These contributions outweigh those of increased temperatures and $\mathrm{CO}_{2}$ fertilisation $\left(+78 \mathrm{TgC} \mathrm{Cyr}^{-1}\right)$. Other studies have found that land use change (e.g. Wu et al., 2012) or $\mathrm{CO}_{2}$ inhibition (e.g. Heald et al., 2009; Young et al., 2009; Arneth et al., 2007b) can separately compensate for the isoprene emission increase caused by temperature and $\mathrm{CO}_{2}$ fertilisation over the 21 st century, leaving little overall change in global isoprene emissions since present-day. Assuming, as in our study, that the land use scenario projects an overall decrease in isoprene emitters, it follows that the combined effect of both land use change and $\mathrm{CO}_{2}$ inhibition should lead to a decrease in global isoprene emissions as found here. It is important to note though that as calculating future global isoprene emission changes involves a number of terms, each of which is uncertain, the overall balance between these terms has a high degree of uncertainty.

\section{Attribution of changes in future ozone}

In this section the results of the UM-UKCA integrations are analysed in order to attribute changes in $\mathrm{O}_{3}$ over the 21 st century to changes in climate, isoprene emissions with climate, anthropogenic emissions, land use and $\mathrm{CO}_{2}$ inhibition of isoprene emissions. Prior to the analysis we briefly evaluate the tropospheric $\mathrm{O}_{3}$ calculated by UM-UKCA by comparison to measurements.

\subsection{Model evaluation}

As shown in Fig. 2, the largest changes in isoprene emissions are in the tropics. We therefore expect this region to show large changes in $\mathrm{O}_{3}$. To have confidence in any calculated changes, it is important that tropical $\mathrm{O}_{3}$ compares favourably with measurements, and this is examined in Fig. 3. Figure 3 shows vertical profiles of $\mathrm{O}_{3}$ at selected sites, and calculated by UM-UKCA. Additionally, Fig. 4 shows calculated present-day near-surface $\mathrm{O}_{3}$ and the locations of the measurement sites used in Fig. 3. The measurements in Fig. 3 were taken from the Southern Hemisphere ADditional OZonesondes (SHADOZ) network (Thompson et al., 2003). Quoted are the correlation coefficients calculated by the Pearson method $\left(R^{2}\right)$, and the mean bias error (MBE). The MBE is given as a percentage and calculated as in Eq. (1).

$\mathrm{MBE}=\left(\frac{\overline{\mathrm{MOD}}-\overline{\mathrm{MES}}}{\overline{\mathrm{MES}}}\right) \times 100$

Here $\overline{\mathrm{MOD}}$ and $\overline{\mathrm{MES}}$ are the mean of the modelled and measured data respectively. Although there are some locations where $R^{2}$ is low (Java) or MBE is high (Kuala Lumpur), in general our modelled results compare favourably. Correlation is generally good, with most $R^{2}$ values lying between 0.9 and 1 . The average MBE is $+23 \%$, suggesting a weak positive model bias consistent with Telford et al. (2013), however the MBE is within the monthly variability of the data in all but one site (Kuala Lumpur). In some locations there tends to be a divergence in the $\mathrm{O}_{3}$ trend at altitudes above 


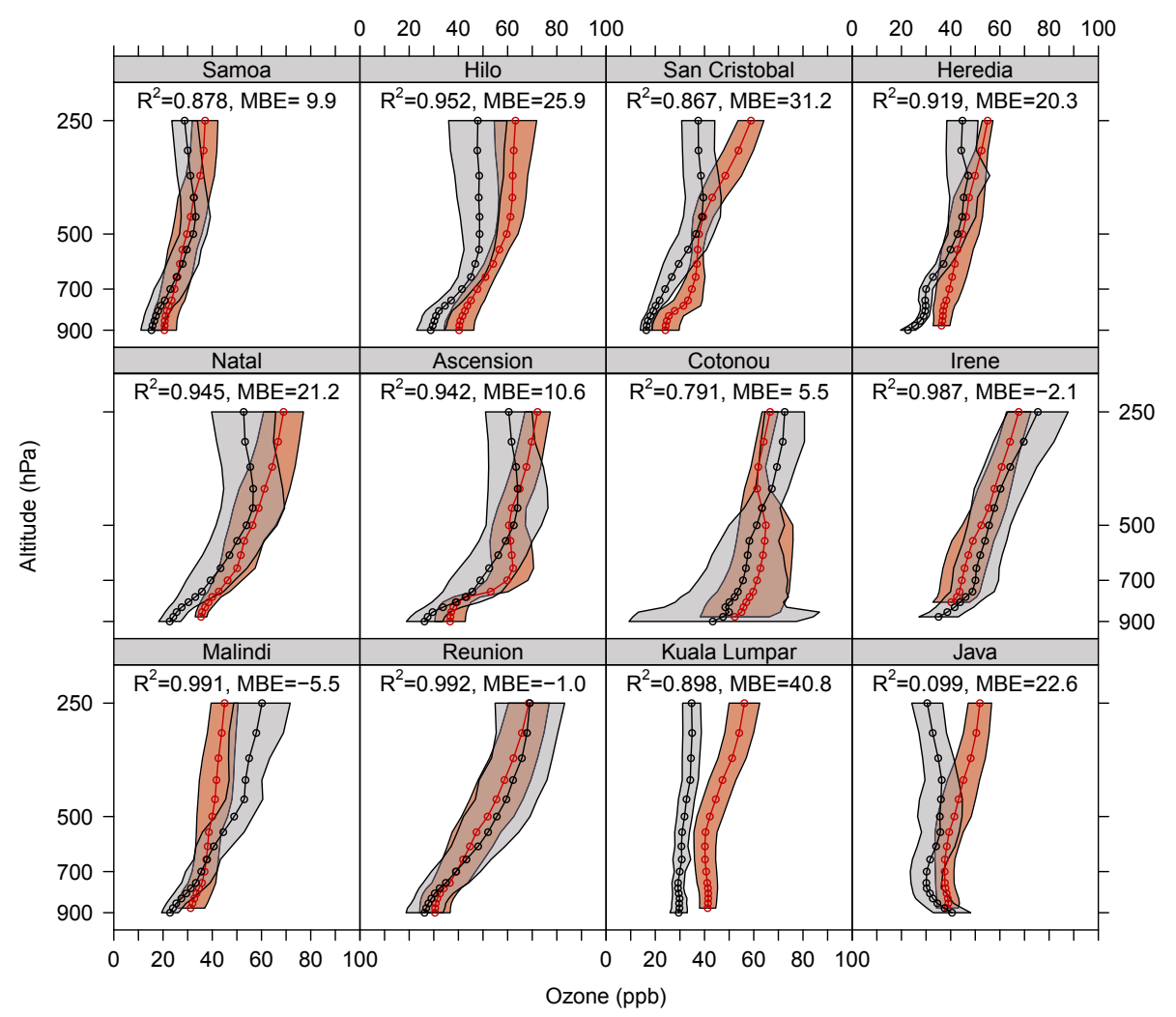

Fig. 3. Five-year mean $\mathrm{O}_{3}$ (ppb) from the BASE run (red) compared to $\mathrm{O}_{3}$ sonde data from the SHADOZ Network (Thompson et al., 2003) (black). Polygons show extent of monthly variability. Correlation coefficients $\left(R^{2}\right)$ are calculated using the Pearson method. Mean bias errors $(\mathrm{MBE})$ are in \%; positive values indicate the model is biased high with respect to the measurement data.

Table 2. Changes in the $\mathrm{O}_{\mathrm{x}}$ budget $\left(\mathrm{Tg} \mathrm{yr}^{-1}\right)$ from the present-day BASE integration caused by the change in various factors between present-day and 2095. Also quoted are changes in the $\mathrm{O}_{3}$ burden (Tg). Percentage changes are in brackets.

\begin{tabular}{lllllll}
\hline Tg yr $^{-1}$ & Prod & Loss & Net Chem & Influx & Dry Dep & Burden $(\mathrm{Tg})$ \\
\hline BASE & 6188 & 5602 & 586 & 673 & 1259 & 379 \\
\hline$\Delta$ Climate & $+393(+6)$ & $+546(+10)$ & $-153(-26)$ & $+144(+21)$ & $-8(-1)$ & $+7(+2)$ \\
$\Delta$ Isoprene Ems & $+56(+1)$ & $+64(+1)$ & $-8(-1)$ & $+15(+2)$ & $+6(0)$ & $+3(+1)$ \\
$\begin{array}{l}\text { with } \Delta \text { climate) } \\
\Delta \text { Anthrop Ems }\end{array}$ & $-199(-3)$ & $-118(-2)$ & $-81(-14)$ & $+33(+5)$ & $-48(-4)$ & $-4(-1)$ \\
$\Delta$ Land Use & $-286(-5)$ & $-296(-5)$ & $+10(+2)$ & $-45(-7)$ & $-35(-3)$ & $-19(-5)$ \\
$\Delta \mathrm{CO}_{2}$ Inhibition & $-270(-4)$ & $-284(-5)$ & $+14(+2)$ & $-46(-7)$ & $-32(-3)$ & $-16(-4)$ \\
$\Delta$ All factors & $-263(-4)$ & $-33(-1)$ & $-230(-39)$ & $+116(+17)$ & $-115(-9)$ & $-27(-7)$ \\
\hline
\end{tabular}

$\sim 500 \mathrm{hPa}$, however this is not generally the case at lower altitudes, which are more pertinent to this study.

The near-surface $\mathrm{O}_{3}$ modelled by UM-UKCA in Fig. 4 generally shows higher $\mathrm{O}_{3}$ in the Northern Hemisphere with peaks over the Mediterranean and Middle East, coastal USA, Tibetan Plateau and the region of the East China Sea. Lows are over remote oceanic regions, most pronounced over the Western Pacific, and the rainforests (most notably the Amazon). This spatial pattern and the magnitude of tropospheric $\mathrm{O}_{3}$ compares favourably to the ACCMIP ensemble mean in
Young et al. (2013). For a more extensive evaluation of UMUKCA see Telford et al. (2010) and O'Connor et al. (2013).

\subsection{Ozone changes}

Figure 5 shows how the near-surface tropospheric $\mathrm{O}_{3}$ mixing ratio changes between 2000 and 2095 in the UM-UKCA integrations as caused by the different environmental variables mentioned previously. In Table 2 we report $\mathrm{O}_{\mathrm{x}}$ budgets for the integrations, which compare tropospheric chemical production and loss of $\mathrm{O}_{\mathrm{x}}$ with its source from the stratosphere 


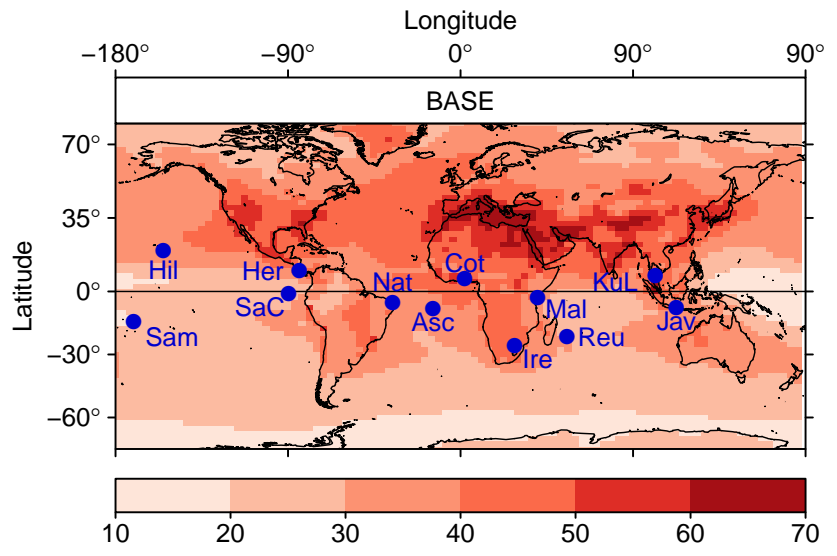

Fig. 4. Modelled five-year mean near-surface $(<720 \mathrm{~m}) \mathrm{O}_{3}(\mathrm{ppb})$ for the year 2000 (BASE). Locations of measurement sites used in Fig. 3 are shown. Sam $=$ Samoa, Hil $=$ Hilo, $\mathrm{SaC}=$ San Chris tobal, Her $=$ Heredia, Nat $=$ Natal, Asc $=$ Ascension, $\mathrm{Cot}=$ Cotonou, Ire $=$ Irene, $\mathrm{Mal}=$ Malindi, $\mathrm{Reu}=$ Reunion, $\mathrm{KuL}=$ Kuala Lumpur, $\mathrm{Jav}=\mathrm{Java}$.

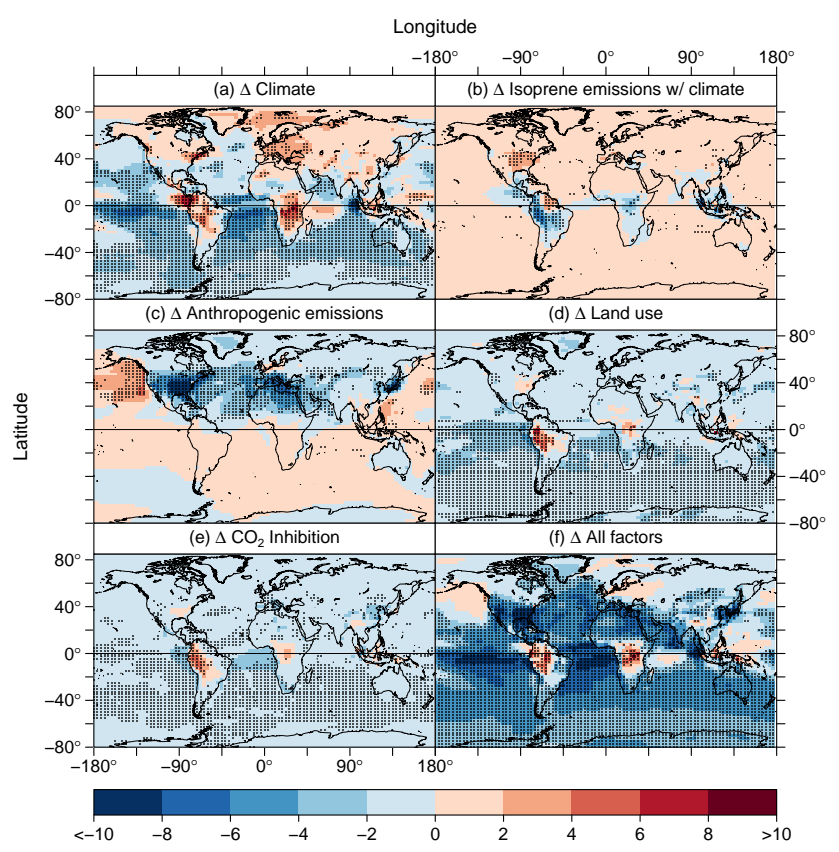

Fig. 5. Changes in five-year mean near-surface $(<720 \mathrm{~m}) \mathrm{O}_{3}$ (2095-2000) caused by different environmental variables. Changes are considered significant (stippled) if they are greater than 2 times the standard deviation for the five-year mean (i.e. approximately the $5 \%$ level).

("influx") and sink to the surface by dry deposition. Here we define $\mathrm{O}_{\mathrm{x}}$ as the sum of $\mathrm{O}_{3}$, atomic oxygen and reactive nitrogen species $\left(\mathrm{NO}_{\mathrm{y}}\right)$.

Figure 5 a shows the effect of climate change on $\mathrm{O}_{3}$. The increased SSTs in the climate change integration cause a general warming of the boundary layer by $1-3{ }^{\circ} \mathrm{C}$. As both $\mathrm{O}_{3}$ production and destruction usually have a positive temper- ature dependence, the expected effect would be an increase in $\mathrm{O}_{3}$ in regions where $\mathrm{O}_{3}$ production dominates (continental regions near a $\mathrm{NO}_{\mathrm{x}}$ source), and a decrease in $\mathrm{O}_{3}$ where there is net $\mathrm{O}_{3}$ destruction (the remote ocean and low- $\mathrm{NO}_{\mathrm{x}}$ high-VOC environments such as the rainforest). This is reflected in both the higher production $\left(+393 \mathrm{Tg} \mathrm{yr}^{-1}(+6 \%)\right)$ and loss $\left(+546 \mathrm{Tgyr}^{-1}(+10 \%)\right)$ terms in the $\mathrm{O}_{\mathrm{x}}$ budget for climate change (Table 2). The effect of higher temperatures on $\mathrm{O}_{\mathrm{x}}$ loss is greater than on $\mathrm{O}_{\mathrm{x}}$ production, leading to an overall decrease in the net chemical tendency. The response of the atmospheric system is to increase the $\mathrm{O}_{3}$ burden by $7 \mathrm{Tg}(2 \%)$, mainly due to increased influx from the stratosphere.

Warming is significantly higher than $1-3^{\circ} \mathrm{C}$ over some regions, notably Brazil and high northern latitudes $\left(6-8^{\circ} \mathrm{C}\right)$. The particularly strong warming over Brazil causes water vapour to decrease, following a drying of the surface. Even though this rainforest-covered region is an area where $\mathrm{O}_{3}$ destruction dominates, the reduction in water vapour diminishes the potential for $\mathrm{O}_{3}$ loss through the $\mathrm{O}^{1} \mathrm{D}+\mathrm{H}_{2} \mathrm{O}$ reaction, leading to $\mathrm{O}_{3}$ increases. Over the oceans the opposite effect occurs, with higher temperatures leading to increased atmospheric water vapour and increased $\mathrm{O}_{3}$ loss through $\mathrm{O}^{1} \mathrm{D}+\mathrm{H}_{2} \mathrm{O}$.

Another factor influencing $\mathrm{O}_{3}$ over the oceans is the change in long-range transport of peroxyacetyl nitrate (PAN). PAN is produced over land where $\mathrm{NO}_{\mathrm{x}}$ and VOCs interact. As shown in Fig. 6a major source regions are the continental tropics, southeast USA, Europe and Southeast Asia. Transport of PAN, and subsequent thermal decomposition, provides a source of $\mathrm{NO}_{\mathrm{x}}$ (leading possibly to $\mathrm{O}_{3}$ production) over the remote oceans. PAN decomposition is very strongly temperature dependent; in a warmer climate PAN transport to the remote ocean is reduced. The largest reductions in PAN are calculated over South America (Fig. 6b) where PAN production is high in the BASE run, and the increase in temperature under climate change is the largest. This contributes to decreases in $\mathrm{O}_{3}$ of up to $8 \mathrm{ppb}(\sim 23 \%)$ in the surrounding oceans.

The largest changes in isoprene emissions due to climate change (Fig. 2c) occurred in the tropics and may be summarised as generally elevated emissions except in the northeast Amazon and parts of the Maritime Continent. Isoprene emissions are also heightened to a smaller degree over southeast USA. The effect of these isoprene emission changes on $\mathrm{O}_{3}$ is shown in Fig. 5b. The tropical lower troposphere is $\mathrm{NO}_{\mathrm{x}}$-limited and VOC-rich. Accordingly, where isoprene emissions increase in the tropics, decreases in $\mathrm{O}_{3}$ are calculated. This is due to increased ozonolysis of isoprene by $\mathrm{O}_{3}$ and greater sequestration of $\mathrm{NO}_{\mathrm{x}}$ as isoprene nitrates. Where isoprene decreases in the tropics the opposite effects occur, and $\mathrm{O}_{3}$ increases. In contrast, the increases in isoprene emissions in the VOC-limited eastern USA cause $\mathrm{O}_{3}$ to increase by $2-4 \mathrm{ppb}(\sim 5 \%)$. Similar, regionally heterogeneous $\mathrm{O}_{3}$ responses to isoprene emissions were calculated in 


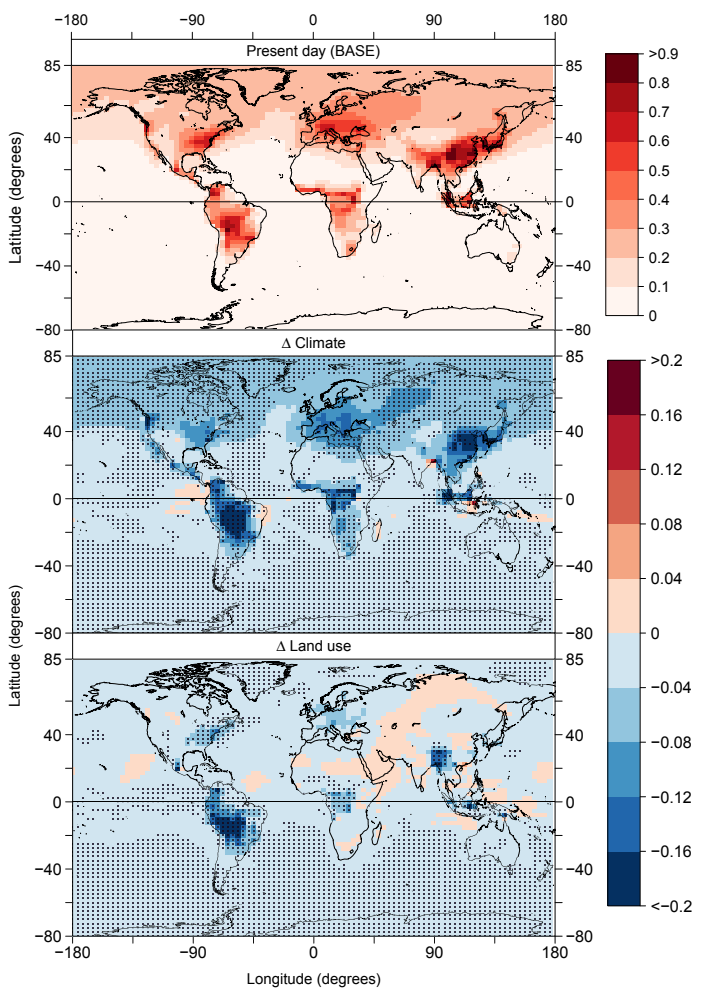

Fig. 6. Five-year mean near-surface $(<720 \mathrm{~m})$ PAN (ppb) in (a) BASE. (b-c) give the change in PAN due to (b) climate and (c) land use between future and present-day (2095-2000). The changes in (b-c) are considered significant (stippled) if they are greater than 2 times the standard deviation for the five-year mean (i.e. approximately the $5 \%$ level).

Wiedinmyer et al. (2006); Zeng et al. (2008); Young et al. (2009); Ganzeveld et al. (2010); Wu et al. (2012). Conversely, Sanderson et al. (2003) calculated increases in $\mathrm{O}_{3}$ wherever isoprene increased regardless of whether the environment was $\mathrm{NO}_{\mathrm{x}}$ or VOC-limited. As noted by Young et al. (2009) this may be attributed to the lack of an isoprenenitrate $\mathrm{NO}_{\mathrm{x}}$ sink in the Sanderson et al. (2003) study. With such a chemical scheme, increasing isoprene emissions in a $\mathrm{NO}_{\mathrm{x}}$-limited environment would not decrease $\mathrm{NO}_{\mathrm{x}}$ and the effects of increased isoprene $+\mathrm{OH}$ could dominate, leading overall to an increase in $\mathrm{O}_{3}$ production. We discuss the sensitivity of our results to such changes in the isoprene mechanism in a companion paper (Squire et al., 2014). Overall the addition of $78 \mathrm{TgC} \mathrm{yr}^{-1}$ of isoprene into UM-UKCA causes both production and destruction rates of $\mathrm{O}_{3}$ to increase (Table 2). The net chemical tendency is a decrease of $8 \mathrm{Tg} \mathrm{yr}^{-1}$ $(1 \%)$, which is to be expected as the largest increases in isoprene emissions are in the tropics, where isoprene acts as an $\mathrm{O}_{3}$ sink.

Figure $5 \mathrm{c}$ illustrates the change in $\mathrm{O}_{3}$ between 2000 and 2095 solely due to changes in anthropogenic emissions. The $\mathrm{O}_{3}$ changes generally follow those of $\mathrm{NO}_{\mathrm{x}}$ emissions. In the
B2 + CLE scenario large emission cuts occur across North America, Europe and Japan, whilst the emerging economies increase emissions, but by a much smaller amount than the decreases in the developed countries. Accordingly, the largest calculated changes in $\mathrm{O}_{3}$ are decreases centred around those developed northern hemispheric regions, with the highest $\mathrm{O}_{3}$ reductions occurring across eastern USA $(\sim 12 \mathrm{ppb}$ $(\sim 22 \%)$ ). Decreases in $\mathrm{NO}_{\mathrm{x}}$ across Europe and USA are large and many grid cells go from being VOC-limited to $\mathrm{NO}_{\mathrm{x}}$-limited (we define VOC-limited and $\mathrm{NO}_{\mathrm{x}}$-limited as when the ratio of $L_{N}$ to $Q$ is more than 0.5 or less than 0.5 respectively, where $L_{N}=$ the loss of radicals from reactions with $\mathrm{NO}$ and $\mathrm{NO}_{2}, Q=$ the sum of all radical sinks; Kleinman et al., 1997; Wiedinmyer et al., 2006). Once into the $\mathrm{NO}_{\mathrm{x}}{ }^{-}$ limited regime, further decreases in $\mathrm{NO}_{\mathrm{x}}$ lead to decreases in $\mathrm{O}_{3}$, as seen in Fig. 5c. The large reductions in $\mathrm{NO}_{\mathrm{x}}$ lead to a lowering of the net chemical tendency of $\mathrm{O}_{3}$ by $81 \mathrm{Tg} \mathrm{yr}^{-1}$ $(14 \%)$ but a smaller reduction in the $\mathrm{O}_{3}$ burden $(4 \mathrm{Tg}(1 \%))$.

Land use change causes a decrease in isoprene emissions across the tropics, mainland Southeast Asia and southeast USA (Fig. 2d). In the $\mathrm{NO}_{\mathrm{x}}$-limited VOC-rich tropics this leads to an increase in $\mathrm{O}_{3}$ (Fig. 5d). Isoprene oxidation produces peroxyacetyl radicals, which are a precursor to PAN formation, so that the effect of reducing isoprene emissions through cropland expansion is to decrease PAN (Fig. 6c). The greatest decreases occur over South America and Southeast Asia, and subsequently this reduction in PAN leads to a drop in $\mathrm{O}_{3}$ over the remote tropical oceans by up to $6 \mathrm{ppb}$ $(\sim 24 \%)$ ). Whilst the global reduction in isoprene emissions $\left(-190 \mathrm{Tg} \mathrm{Cyr}^{-1}\right)$ leads to less $\mathrm{O}_{\mathrm{x}}$ production, less $\mathrm{O}_{\mathrm{x}}$ loss, and ultimately less tropospheric $\mathrm{O}_{3}\left(\mathrm{O}_{3}\right.$ burden is reduced by $19 \mathrm{Tg}(5 \%)$ ), overall the $\mathrm{O}_{\mathrm{x}}$ net chemical tendency increases by $10 \mathrm{Tg} \mathrm{yr}^{-1}(7 \%)$. This is a result of reducing isoprene in the $\mathrm{NO}_{\mathrm{x}}$-limited tropics where it acts as a direct sink for $\mathrm{O}_{3}$.

Altering land use affects the deposition velocity of $\mathrm{O}_{3}$ (Fig. 7). In UM-UKCA, $\mathrm{O}_{3}$ is deposited to broad-leaved trees with a higher velocity $\left(0.525 \mathrm{~cm} \mathrm{~s}^{-1}\right)$ than to crops $\left(0.450 \mathrm{~cm} \mathrm{~s}^{-1}\right)$. Hence, in those regions where broad-leaved trees are replaced by crops (e.g. the tropics) the deposition velocity decreases. Reduction of this $\mathrm{O}_{3}$ sink further increases atmospheric $\mathrm{O}_{3}$ in these regions. On the other hand, increases in the deposition velocity are modelled where crops replace bare soil $\left(\right.$ deposition velocity $=0.180 \mathrm{~cm} \mathrm{~s}^{-1}$ ), e.g. in central Asia. Although a much smaller fraction of land is converted to crops from bare soil compared to from broadleaved trees (see Fig. 1b, c), proportionally the change in the deposition velocity is greater as the difference in deposition velocity between bare soil and crops $\left(0.27 \mathrm{~cm} \mathrm{~s}^{-1}\right)$ is larger than that between crops and broad-leaved trees $\left(0.075 \mathrm{~cm} \mathrm{~s}^{-1}\right)$.

In $\mathrm{NO}_{\mathrm{x}}$-limited regions changes in $\mathrm{NO}_{\mathrm{x}}$ emissions associated with land use have the potential to alter $\mathrm{O}_{3}$. Despite this, for the case of cropland expansion Ganzeveld et al. (2010) calculated that the two competing effects on $\mathrm{NO}_{\mathrm{x}}$ emissions, (i) the increase caused by more intensive fertiliser use and 


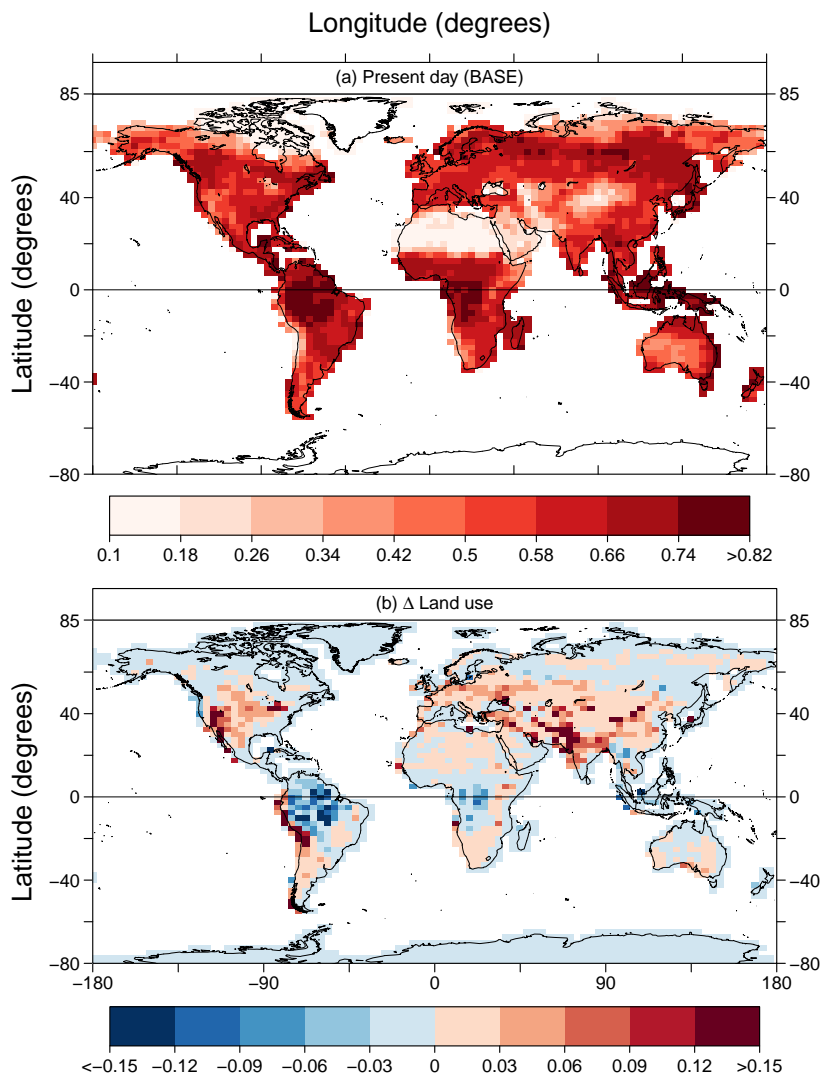

Fig. 7. $\mathrm{O}_{3}$ deposition velocity over land $\left(\mathrm{cm} \mathrm{s}^{-1}\right)$ for (a) presentday (i.e. without land use change), and (b) with future land use change. Negative values indicate a decrease in the deposition velocity due to land use change.

(ii) the decrease caused by the lower emission factor of crops compared to broad-leaved forest (Yienger and Levy, 1995), resulted in little overall change. In this study changes in $\mathrm{NO}_{\mathrm{x}}$ emissions accompanying land use change have not been considered.

Including future changes in the $\mathrm{CO}_{2}$ inhibition of isoprene emissions causes $\mathrm{O}_{3}$ to increase near the isoprene source regions and decrease in remote regions (Fig. 5e). Decreases in remote regions are due to decreased PAN formation. The largest $\mathrm{O}_{3}$ increases $(3-5 \mathrm{ppb}(\sim 27 \%))$ are calculated in the tropics where the $\mathrm{NO}_{\mathrm{x}}: \mathrm{VOC}$ ratio is lowest $\left(L_{N} / Q \approx 0.1\right)$. In Southeast Asia and southeast USA (the other high isoprene emitting regions) the $\mathrm{NO}_{\mathrm{x}}$ : VOC ratio is higher $\left(L_{N} / Q \approx 0.3\right)$. Whilst this ratio still categorises these regions as $\mathrm{NO}_{\mathrm{X}}$-limited, the higher ratio signifies that $\mathrm{O}_{3}$ production will be less sensitive to decreases in isoprene emissions. So, increases in $\mathrm{O}_{3}$ are much smaller (less than $1 \mathrm{ppb}$ ). In these regions Young et al. (2009) calculated decreases in $\mathrm{O}_{3}$ of up to $10 \mathrm{ppb}$ due to $\mathrm{CO}_{2}$ inhibition. In their study $\mathrm{NO}_{\mathrm{x}}$ emissions were higher in the Northern Hemisphere in line with the A2 scenario, so these regions were VOC-limited. We use the lower anthropogenic emissions of the B2 + CLE scenario, resulting instead in $\mathrm{NO}_{\mathrm{x}}$-limited conditions in the northern hemispheric isoprene emitting regions. The effect of $\mathrm{CO}_{2}$ inhibition on the $\mathrm{O}_{\mathrm{x}}$ net chemical tendency is similar to that of land use change $\left(+14 \mathrm{Tgyr}^{-1}(1.7 \%)\right.$ and $+10 \mathrm{Tg} \mathrm{yr}^{-1}(2.4 \%)$ respectively), with the largest changes in isoprene emissions occurring in similar areas.

The combined effect of all factors on near-surface $\mathrm{O}_{3}$ (Fig. 5f) is to cause increases of up to $9 \mathrm{ppb}(\sim 30 \%)$ over the tropical land masses, and decreases in remote regions, as well as over eastern USA and Japan, of more than $10 \mathrm{ppb}$ $(\sim 18 \%)$. Changes in climate, land use and $\mathrm{CO}_{2}$ inhibition of isoprene emissions contribute most to the increases in the tropics and the decreases in remote regions. Anthropogenic emission changes are largely responsible for the reductions calculated over eastern USA and Japan. Over the entire troposphere, the lowering of chemical $\mathrm{O}_{\mathrm{x}}$ production caused by changes in anthropogenic emissions, land use and $\mathrm{CO}_{2}$ inhibition is not compensated for by the increases caused by changes in climate and isoprene emissions with climate (change in net production $=-263 \mathrm{Tgyr}^{-1}(4 \%)$, Table 2), but this is practically the case for $\mathrm{O}_{\mathrm{x}}$ loss $\left(-33 \mathrm{Tg} \mathrm{yr}^{-1}\right.$ $(<1 \%))$. Accordingly, net chemical production is down by $230 \mathrm{Tg} \mathrm{yr}^{-1}$ (39\%) compared to the BASE case. Overall, compared to the BASE integration the $\mathrm{O}_{3}$ burden decreases by $27 \mathrm{Tg}(7 \%)$ to $352 \mathrm{Tg}$. In conclusion, future climate, land use and $\mathrm{CO}_{2}$ inhibition of isoprene emissions lead to increases in tropospheric $\mathrm{O}_{3}$ of up to $8 \mathrm{ppb}(\leq 50 \%)$ in the tropics. Climate and land use also drive oceanic $\mathrm{O}_{3}$ decreases of up to $10 \mathrm{ppb}(\leq \sim 40 \%)$, and anthropogenic emission changes cause $\mathrm{O}_{3}$ reductions of more than $10 \mathrm{ppb}(\sim 18 \%)$ in the industrialised northern hemispheric regions.

\section{Changes in ozone-induced vegetation damage}

As shown in Fig. 1, in our land use change scenario there is widespread cropland expansion largely at the expense of broad-leaved trees. The change in isoprene emissions that this causes led to higher $\mathrm{O}_{3}$ in some locations, most notably in the tropics (Fig. 5d). The tropical regions (the Amazon, central Africa and the Maritime Continent) were also the areas with the largest increases in cropland. In this section we investigate whether the increases in $\mathrm{O}_{3}$ caused by cropland expansion are sufficient to lead to an increase in $\mathrm{O}_{3}$ oxidation damage to the crops. If this is the case, then cropland expansion in these regions may not be an efficient solution to feeding the world's growing population.

We examine all regions where cropland expansion is large: the three tropical regions of the Amazon, central Africa and the Maritime Continent where $\mathrm{O}_{3}$ increases are calculated, and regions of cropland expansion in the Northern Hemisphere (USA, Europe and China). Crop exposure to harmful levels of $\mathrm{O}_{3}$ is quantified using the AOT40. The World Health Organization recommend that over the daylight hours of a three-month growing season (when stomatal uptake of 


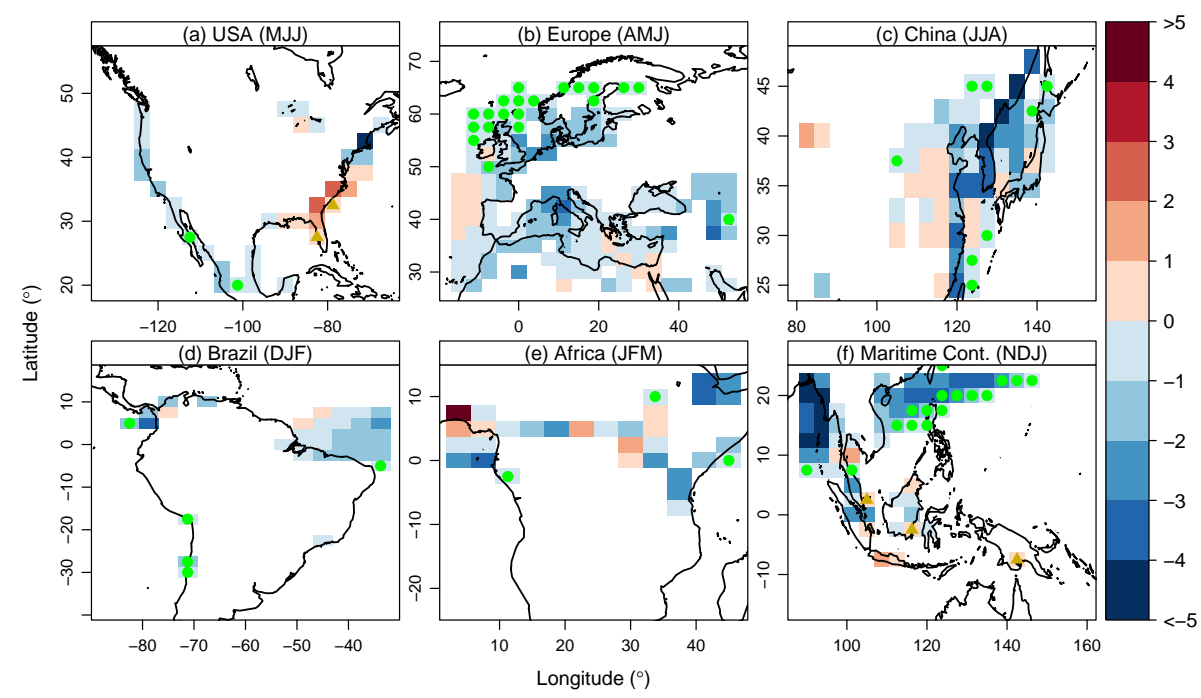

Fig. 8. Change in AOT40 > 3 ppm h during the daylights hours of the regional three-month growing season caused by cropland expansion. Growing seasons are quoted, e.g. MJJ = May, June, July. White areas are where both without and with cropland expansion the AOT40 is below the threshold. Green circles indicate crossing to below the threshold. Gold triangles indicate crossing to above the threshold.

$\mathrm{O}_{3}$ typically occurs), the AOT40 should not exceed $3 \mathrm{ppm} \mathrm{h}$ in total (WHO, 2000). Figure 8 shows the change in the daylight AOT40 above this threshold caused by cropland expansion, following this guideline for the primary three-month growing season for each region. Daylight hours are defined as 06:00-18:00 LT. Growing seasons are established from maps of planting and harvest dates compiled by Sacks et al. (2010). We assume that growing seasons will not change with climate change, although we acknowledge that this is a probability. For this reason, we have also calculated changes in the AOT40 over the rest of the year (not shown), but this had little effect on the overall trends.

In Fig. 8, the coloured areas that contain no symbol are above the threshold both with and without cropland expansion. Blue areas are where exposure to harmful levels of $\mathrm{O}_{3}$ has become less severe but is still over the threshold, and red areas are where it has become worse. Around coastal southeast USA there are increases in the AOT40 above $3 \mathrm{ppm} \mathrm{h}$ of up to $3 \mathrm{ppm} \mathrm{h}$, however globally there are more grid cells where a decrease is calculated (e.g. coastal regions of China). In all domains, Fig. 8 is dominated by large areas where the AOT40 is below the threshold both in the cases with and without cropland expansion (white). From this it is clear that in most areas cropland expansion does not increase crop exposure to harmful levels of $\mathrm{O}_{3}$ in the integrations. In fact it is only in those grid cells that are marked by gold triangles (signifying where the AOT40 crosses from below to above the threshold) where this is the case. This only occurs in a very small number of grid cells in southeast USA and across the Maritime Continent. If anything, cropland expansion has a small positive impact on air quality, as there are more grid cells marked with a green circle, which signifies that cropland expansion has caused the AOT40 to drop below the threshold. These areas are however generally coastal or over the open ocean and so away from areas of crops.

From Fig. 8 we can conclude that the increases in $\mathrm{O}_{3}$ calculated over the tropical regions (see Fig. 5d) where the greatest cropland expansion occurs, are actually changes from very low $\mathrm{O}_{3}$ levels to higher values that are still below the threshold above which $\mathrm{O}_{3}$ exposure is considered damaging. As such, we can state that under the conditions used in these model runs, cropland expansion over the 21 st century does not cause a widespread increase in crop exposure to harmful levels of $\mathrm{O}_{3}$. It should be noted however that this conclusion is dependent on the land use change scenario employed. The degree of $\mathrm{O}_{3}$ damage could be different if, for example, broad-leaved rainforest was replaced instead with higher isoprene emitting species such as oil palm.

\section{Conclusions}

Future (2095) isoprene emissions were calculated with a biogenic emissions model based on MEGAN (Guenther et al., 2006) using vegetation distributions generated by the SDGVM (Beerling et al., 1997; Beerling and Woodward, 2001; Lathière et al., 2010). These allow us to examine the contribution of changes in climate (temperature and $\mathrm{CO}_{2}$ levels), land use and $\mathrm{CO}_{2}$ inhibition to changes in isoprene emissions over the 21 st century. When all future conditions are taken together, isoprene emissions decrease globally by $259 \mathrm{TgCyr}^{-1}(55 \%)$. In this case the net decrease was due to the larger reductions in emissions caused by anthropogenic land use change $\left(-190 \mathrm{Tg} \mathrm{Cyr}^{-1}\right.$ $(41 \%))$ and $\mathrm{CO}_{2}$ inhibition change $\left(-147 \mathrm{TgC} \mathrm{Cyr}^{-1}(31 \%)\right)$ 
compared to the amplification of emissions due to climate change (+78 $\left.\mathrm{TgCyr}^{-1}(17 \%)\right)$. We note that the climate change impact is particularly sensitive to changes in tropical soil moisture (the "die-back" effect) and that this differs significantly between models (e.g. Heald et al., 2009 vs. Sanderson et al., 2003). Resolving this uncertainty is a critical issue for chemistry-climate modelling.

Using these isoprene emissions, a series of chemistryclimate integrations were conducted with UM-UKCA in order to attribute changes in $\mathrm{O}_{3}$ over the 21 st century to changes in climate, isoprene emissions with climate, anthropogenic emissions, cropland expansion, and $\mathrm{CO}_{2}$ inhibition of isoprene emissions. Globally we calculate a decrease in the tropospheric $\mathrm{O}_{3}$ burden of $27 \mathrm{Tg}(7 \%)$ from $379 \mathrm{Tg}$ in the present-day to $352 \mathrm{Tg}$ in 2095 when all future changes are combined. At the surface, decreases in $\mathrm{O}_{3}$ are calculated over the oceans and are greatest in the tropical oceans $(6$ to $>10 \mathrm{ppb}($ maximum $\sim 41 \%)$ ). The oceanic $\mathrm{O}_{3}$ reduction was caused by decreases in $\mathrm{NO}_{\mathrm{x}}$ transport to the oceans by PAN as a result of (i) higher temperatures due to climate change and (ii) a reduction in tropical isoprene emissions due to changes in land use and $\mathrm{CO}_{2}$ inhibition. There are also decreases calculated in $\mathrm{O}_{3}$ over the USA, southern Europe and Japan of $6-10 \mathrm{ppb}(\sim 18 \%)$ which are driven by decreases in future anthropogenic $\mathrm{NO}_{\mathrm{x}}$ emissions in these regions in the $\mathrm{B} 2+\mathrm{CLE}$ scenario. Increases in $\mathrm{O}_{3}$ of $4-8 \mathrm{ppb}$ (maximum $\sim 50 \%$ ) are calculated over the tropical regions of the Amazon, central Africa and the Maritime Continent. Isoprene acts as an $\mathrm{O}_{3}$ sink in the tropics, so these increases are attributable to the reduction in isoprene emissions caused by cropland expansion and increased $\mathrm{CO}_{2}$ inhibition. Higher temperatures and lower water vapour due to climate change, as well as die-back of isoprene-emitting vegetation in some tropical regions, also contributes to increased $\mathrm{O}_{3}$. Our land use change scenario consists of cropland expansion, which is largest in the tropics, and this is also where land use causes the greatest increases in $\mathrm{O}_{3}$. As such, there is potential for increased crop exposure to harmful levels of $\mathrm{O}_{3}$. However, we find that these $\mathrm{O}_{3}$ changes are generally small and not large enough to raise $\mathrm{O}_{3}$ levels over the threshold above which $\mathrm{O}_{3}$ is considered harmful, though we acknowledge that this conclusion depends on the land use change scenario employed. In a companion paper (Squire et al., 2014) we will examine the sensitivity of these conclusions to the choice of isoprene chemical mechanism used.

Acknowledgements. This work was supported by NERC and ERC, under project no 267760 - ACCI. O. J. Squire would like to acknowledge NERC for a PhD studentship. The work done by J. Lathiere and R. C. Pike was supported by QUEST. R. C. Pike would like to acknowledge the Gates Trust for funding.

Edited by: J. West

\section{References}

Alcamo, K. E.: Global Chan Scenarios of the 21st Century: Results from the IMAGE 2.1 Model, Pergamon/Elsevier Science, Oxford, UK, 1999.

Archibald, A. T., Cooke, M. C., Utembe, S. R., Shallcross, D. E., Derwent, R. G., and Jenkin, M. E.: Impacts of mechanistic changes on $\mathrm{HO}_{\mathrm{x}}$ formation and recycling in the oxidation of isoprene, Atmos. Chem. Phys., 10, 8097-8118, doi:10.5194/acp-108097-2010, 2010.

Arneth, A., Miller, P., Scholze, M., Hickler, T., Schurgers, G., Smith, B., and Prentice, I.: $\mathrm{CO}_{2}$ inhibition of global terrestrial isoprene emissions: Potential implications for atmospheric chemistry, Geophys. Res. Lett., 34, L18813, doi:10.1029/2007GL030615, 2007.

Arneth, A., Monson, R. K., Schurgers, G., Niinemets, Ü., and Palmer, P. I.: Why are estimates of global terrestrial isoprene emissions so similar (and why is this not so for monoterpenes)?, Atmos. Chem. Phys., 8, 4605-4620, doi:10.5194/acp-8-46052008, 2008.

Ashmore, M.: Assessing the future global impacts of ozone on vegetation, Plant Cell Environ., 28, 949-964, 2005.

Ashworth, K., Folberth, G., Hewitt, C. N., and Wild, O.: Impacts of near-future cultivation of biofuel feedstocks on atmospheric composition and local air quality, Atmos. Chem. Phys., 12, 919 939, doi:10.5194/acp-12-919-2012, 2012.

Ashworth, K., Wild, O., and Hewitt, C.: Impacts of biofuel cultivation on mortality and crop yields, Nature Clim. Change, 3, 492 496, 2013.

Avnery, S., Mauzerall, D., Liu, J., and Horowitz, L.: Global crop yield reductions due to surface ozone exposure: 2. Year 2030 potential crop production losses and economic damage under two scenarios of $\mathrm{O}_{3}$ pollution, Atmos. Environ., 45, 2297-2309, $2011 \mathrm{a}$.

Avnery, S., Mauzerall, D., Liu, J., and Horowitz, L.: Global crop yield reductions due to surface ozone exposure: 1. Year 2000 crop production losses and economic damage, Atmos. Environ., 45, 2284-2296, 2011b.

Beerling, D. and Woodward, F.: Vegetation and the Terrestrial Carbon Cycle: The First 400 Million Years, Cambridge University Press, Cambridge, UK, p. 405, 2001.

Beerling, D., Woodward, F., Lomas, M., and Jenkins, A.: Testing the responses of a dynamic global vegetation model to environmental change: a comparison of observations and predictions, Global Ecol. Biogeogr., 6, 439-450, 1997.

Cox, P., Betts, R., Jones, C., Spall, S., and Totterdell, I.: Acceleration of global warming due to carbon-cycle feedbacks in a coupled climate model, Nature, 408, 184-187, 2000.

Cox, P., Betts, R., Collins, M., Harris, P., Huntingford, C., and Jones, C.: Amazonian forest dieback under climate-carbon cycle projections for the 21 st century, Theor. Appl. Climatol., 78, 137-156, 2004.

Dentener, F., Stevenson, D., Cofala, J., Mechler, R., Amann, M., Bergamaschi, P., Raes, F., and Derwent, R.: The impact of air pollutant and methane emission controls on tropospheric ozone and radiative forcing: CTM calculations for the period 1990 2030, Atmos. Chem. Phys., 5, 1731-1755, doi:10.5194/acp-51731-2005, 2005.

Dodge, M.: Combined use of modeling techniques and smog chamber data to derive ozone-precursor relationships, in: Proceedings 
of the international conference on photochemical oxidant pollution and its control, US Environmental Protection Agency, Research Triangle Park, NC, USA, 881-889, 1977.

Fiore, A. M., Naik, V., Spracklen, D. V., Steiner, A., Unger, N., Prather, M., Bergmann, D., Cameron-Smith, P. J., Cionni, I., Collins, W. J., Dalsoren, S., Eyring, V., Folberth, G. A., Ginoux, P., Horowitz, L. W., Josse, B., Lamarque, J.-F., MacKenzie, I. A., Nagashima, T., O'Connor, F. M., Righi, M., Rumbold, S. T., Shindell, D. T., Skeie, R. B., Sudo, K., Szopa, S., Takemura, T., and Zeng, G.: Global air quality and climate, Chem. Soc. Rev., 41, 6663-6683, 2012.

Fowler, D., Amann, M., Anderson, R., Ashmore, M., Cox, P., Depledge, M., Derwent, D., Peringe, Hewitt, N., Hov, O., Jenkin, M., Kelly, F., Liss, P., Pilling, M., Pyle, J., Slingo, J., and Stevenson, D.: Ground-Level Ozone in the 21st Century: Future Trends, Impacts and Policy Implications, The Royal Society, London, UK, 2008.

Fuchs, H., Bohn, B., Hofzumahaus, A., Holland, F., Lu, K. D., Nehr, S., Rohrer, F., and Wahner, A.: Detection of $\mathrm{HO}_{2}$ by laserinduced fluorescence: calibration and interferences from $\mathrm{RO}_{2}$ radicals, Atmos. Meas. Tech., 4, 1209-1225, doi:10.5194/amt4-1209-2011, 2011.

Fuhrer, J.: Ozone risk for crops and pastures in present and future climates, Naturwissenschaften, 96, 173-194, 2009.

Ganzeveld, L., Bouwman, L., Stehfest, E., van Vuuren, D. P., Eickhout, B., and Lelieveld, J.: Impact of future land use and land cover changes on atmospheric chemistry-climate interactions, J. Geophys. Res., 115, D23301, doi:10.1029/2010JD014041, 2010.

Guenther, A., Karl, T., Harley, P., Wiedinmyer, C., Palmer, P. I., and Geron, C.: Estimates of global terrestrial isoprene emissions using MEGAN (Model of Emissions of Gases and Aerosols from Nature), Atmos. Chem. Phys., 6, 3181-3210, doi:10.5194/acp-63181-2006, 2006.

Heald, C. L., Wilkinson, M. J., Monson, R. K., Alo, C. A., Wang, G., and Guenther, A.: Response of isoprene emission to ambient $\mathrm{CO}_{2}$ changes and implications for global budgets, Glob. Change Biol., 15, 1127-1140, 2009.

Hewitt, C. N., MacKenzie, A. R., Di Carlo, P., Di Marco, C. F., Dorsey, J. R., Evans, M., Fowler, D., Gallagher, M. W., Hopkins, J. R., Jones, C. E., Langford, B., Lee, J. D., Lewis, A. C., Lim, S. F., McQuaid, J., Misztal, P., Moller, S. J., Monks, P. S., Nemitz, E., Oram, D. E., Owen, S. M., Phillips, G. J., Pugh, T. A. M., Pyle, J. A., Reeves, C. E., Ryder, J., Siong, J., Skiba, U., and Stewart, D. J.: Nitrogen management is essential to prevent tropical oil palm plantations from causing groundlevel ozone pollution, Prog. Natl. Acad. Sci. USA, 106, 1844718451, 2009.

Horowitz, L. W., Fiore, A. M., Milly, G. P., Cohen, R. C., Perring, A., Wooldridge, P. J., Hess, P. G., Emmons, L. K., and Lamarque, J.-F.: Observational constraints on the chemistry of isoprene nitrates over the eastern United States, J. Geophys. Res., 112, D12S08, doi:10.1029/2006JD007747, 2007.

Johns, T., Carnell, R., Crossley, J., Gregory, J., Mitchell, J., Senior, C., Tett, S., and Wood, R.: The second Hadley Centre coupled ocean-atmosphere GCM: Model description, spinup and validation, Clim. Dynam., 13, 103-134, 1997.

Kleinman, L., Daum, P., Lee, J., Lee, Y., Nunnermacker, L., Springston, S., Newman, L., WeinsteinLloyd, J., and Sillman, S.:
Dependence of ozone production on NO and hydrocarbons in the troposphere, Geophys. Res. Lett., 24, 2299-2302, 1997.

Lathière, J., Hauglustaine, D., De Noblet-Ducoudre, N., Krinner, G., and Folberth, G.: Past and future changes in biogenic volatile organic compound emissions simulated with a global dynamic vegetation model, Geophys. Res. Lett., 32, L20818, doi:10.1029/2005GL024164, 2005.

Lathière, J., Hewitt, C. N., and Beerling, D. J.: Sensitivity of isoprene emissions from the terrestrial biosphere to 20th century changes in atmospheric $\mathrm{CO}_{2}$ concentration, climate, and land use, Global Change Biol., 24, GB1004, doi:10.1029/2009GB003548, 2010.

Law, K., and Pyle, J.: Modeling trace gas budgets in the troposphere, 1. Ozone and odd nitrogen, J. Geophys. Res., 98, 18377-18400, $1993 \mathrm{a}$.

Law, K., and Pyle, J.: Modeling trace gas budgets in the troposphere. 2. $\mathrm{CH}_{4}$ and CO, J. Geophys. Res., 98, 18401-18412, 1993 b.

Mao, J., Ren, X., Zhang, L., Van Duin, D. M., Cohen, R. C., Park, J.H., Goldstein, A. H., Paulot, F., Beaver, M. R., Crounse, J. D., Wennberg, P. O., DiGangi, J. P., Henry, S. B., Keutsch, F. N., Park, C., Schade, G. W., Wolfe, G. M., Thornton, J. A., and Brune, W. H.: Insights into hydroxyl measurements and atmospheric oxidation in a California forest, Atmos. Chem. Phys., 12, 8009-8020, doi:10.5194/acp-12-8009-2012, 2012.

Misztal, P. K., Nemitz, E., Langford, B., Di Marco, C. F., Phillips, G. J., Hewitt, C. N., MacKenzie, A. R., Owen, S. M., Fowler, D., Heal, M. R., and Cape, J. N.: Direct ecosystem fluxes of volatile organic compounds from oil palms in South-East Asia, Atmos. Chem. Phys., 11, 8995-9017, doi:10.5194/acp-11-89952011, 2011.

Nakicenovic, N., Alcamo, J., Davis, G., de Vries, B., Fenhann, J., Gaffin, S., Gregory, K., Grübler, A., Jung, T., Kram, T., La Rovere, E., Michaelis, L., Mori, S., Morita, T., Pepper, W., Pitcher, H., Price, L., Riahi, K., Roehrl, A., Rogner, H., Sankovski, A., Schlesinger, M., Shukla, P., Smith, S., Swart, R., van Rooijen, S., Victor, N., and Dadi, Z.: IPCC Special Report on Emissions Scenarios, Cambridge University Press, Cambridge, UK, 2000.

Neu, J. L., Prather, M. J., and Penner, J. E.: Global atmospheric chemistry: Integrating over fractional cloud cover, J. Geophys. Res., 112, D11306, doi:10.1029/2006JD008007, 2007.

O'Connor, F. M., Johnson, C. E., Morgenstern, O., Abraham, N. L., Braesicke, P., Dalvi, M., Folberth, G. A., Sanderson, M. G., Telford, P. J., Young, P. J., Zeng, G., Collins, W. J., and Pyle, J. A.: Evaluation of the new UKCA climate-composition model - Part 2: The Troposphere, Geosci. Model Dev. Discuss., 6, 1743-1857, doi:10.5194/gmdd-6-1743-2013, 2013.

Olivier, J. and Berdowski, J.: Global emissions sources and sinks, in: The Climate System, edited by: Balkema, A. A., Swets and Zeitlinger, Leiden, the Netherlands, 33-78, 2001.

Pacifico, F., Folberth, G. A., Jones, C. D., Harrison, S. P., and Collins, W. J.: Sensitivity of biogenic isoprene emissions to past, present, and future environmental conditions and implications for atmospheric chemistry, J. Geophys. Res., 117, D22302, doi:10.1029/2012JD018276, 2012.

Paulot, F., Crounse, J. D., Kjaergaard, H. G., Kuerten, A., St Clair, J. M., Seinfeld, J. H., and Wennberg, P. O.: Unexpected Epoxide Formation in the Gas-Phase Photooxidation of Isoprene, Science, 325, 730-733, 2009. 
Peeters, J., Nguyen, T. L., and Vereecken, L.: $\mathrm{HO}_{\mathrm{x}}$ radical regeneration in the oxidation of isoprene, Phys. Chem. Chem. Phys., 11, 5935-5939, 2009.

Porter, W., Barsanti, K., Baughman, E., and Rosenstiel, T.: Considering the air quality impacts of bioenergy crop production: a case study involving Arundo donax, Environ. Sci. Technol., 46, 9777-9784, 2012.

Pöschl, U., von Kuhlmann, R., Poisson, N., and Crutzen, P.: Development and intercomparison of condensed isoprene oxidation mechanisms for global atmospheric modeling, J. Atmos. Chem., 37, 29-52, 2000.

Possell, M., Hewitt, C., and Beerling, D.: The effects of glacial atmospheric $\mathrm{CO}_{2}$ concentrations and climate on isoprene emissions by vascular plants, Global Change Biol., 11, 60-69, 2005.

Rayner, N., Parker, D., Horton, E., Folland, C., Alexander, L., Rowell, D., Kent, E., and Kaplan, A.: Global analyses of sea surface temperature, sea ice, and night marine air temperature since the late nineteenth century, J. Geophys. Res., 108, 4407, doi:10.1029/2002JD002670, 2003.

Riahi, K., Grubler, A., and Nakicenovic, N.: Scenarios of long-term socio-economic and environmental development under climate stabilization, Technol. Forecast. Soc., 74, 887-935, 2007.

Rinne, H., Guenther, A., Greenberg, J., and Harley, P.: Isoprene and monoterpene fluxes measured above Amazonian rainforest and their dependence on light and temperature, Atmos. Environ., 36, 2421-2426, 2002.

Rosenstiel, T., Potosnak, M., Griffin, K., Fall, R., and Monson, R.: Increased $\mathrm{CO}_{2}$ uncouples growth from isoprene emission in an agriforest ecosystem, Nature, 421, 256-259, 2003.

Sacks, W. J., Deryng, D., Foley, J. A., and Ramankutty, N.: Crop planting dates: an analysis of global patterns, Global Ecol. Biogeogr., 19, 607-620, 2010.

Sanderson, M., Jones, C., Collins, W., Johnson, C., and Derwent, R.: Effect of climate change on isoprene emissions and surface ozone levels, Geophys. Res. Lett., 30, 1936, doi:10.1029/2003GL017642, 2003.

Sillman, S. and He, D. Y.: Some theoretical results concerning $\mathrm{O}_{3}-\mathrm{NO}_{\mathrm{x}}-\mathrm{VOC}$ chemistry and $\mathrm{NO}_{\mathrm{x}}-\mathrm{VOC}$ indicators, J. Geophys. Res., 107, 4659, doi:10.1029/2001JD001123, 2002.

Squire, O. J., Archibald, A. T., and Pyle, J. A.: Influence of isoprene chemical mechanism on changes in tropospheric ozone due to climate and cropland expansion over the 21 st century, in preparation, 2014.

Stott, P. A., Jones, G. S., Lowe, J. A., Thorne, P., Durman, C., Johns, T. C., and Thelen, J.-C.: Transient climate simulations with the HadGEM1 climate model: Causes of past warming and future climate change, J. Climate, 19, 2763-2782, 2006.

Telford, P. J., Lathière, J., Abraham, N. L., Archibald, A. T., Braesicke, P., Johnson, C. E., Morgenstern, O., O'Connor, F. M., Pike, R. C., Wild, O., Young, P. J., Beerling, D. J., Hewitt, C. N., and Pyle, J.: Effects of climate-induced changes in isoprene emissions after the eruption of Mount Pinatubo, Atmos. Chem. Phys., 10, 7117-7125, doi:10.5194/acp-10-7117-2010, 2010.

Telford, P. J., Abraham, N. L., Archibald, A. T., Braesicke, P., Dalvi, M., Morgenstern, O., O'Connor, F. M., Richards, N. A. D., and Pyle, J. A.: Implementation of the Fast-JX Photolysis scheme (v6.4) into the UKCA component of the MetUM chemistry-climate model (v7.3), Geosci. Model Dev., 6, 161177, doi:10.5194/gmd-6-161-2013, 2013.
Thompson, A., Witte, J., McPeters, R., Oltmans, S., Schmidlin, F., Logan, J., Fujiwara, M., Kirchhoff, V., Posny, F., Coetzee, G., Hoegger, B., Kawakami, S., Ogawa, T., Johnson, B., Vomel, H., and Labow, G.: Southern Hemisphere Additional Ozonesondes (SHADOZ) 1998-2000 tropical ozone climatology - 1. Comparison with Total Ozone Mapping Spectrometer (TOMS) and ground-based measurements, J. Geophys. Res., 108, 8238, doi:10.1029/2001JD000967, 2003.

Tingey, D., Manning, M., Grothaus, L., and Burns, W.: Influence of light and temperature on isoprene emission rates from live oak, Physiol. Plantarum, 47, 112-118, 1979.

Van Dingenen, R., Dentener, F., Raes, F., Krol, M., Emberson, L., and Cofala, J.: The global impact of ozone on agricultural crop yields under current and future air quality legislation, Atmos. Environ., 43, 604-618, 2009.

von Kuhlmann, R., Lawrence, M. G., Pöschl, U., and Crutzen, P. J.: Sensitivities in global scale modeling of isoprene, Atmos. Chem. Phys., 4, 1-17, doi:10.5194/acp-4-1-2004, 2004.

Warwick, N. J., Archibald, A. T., Ashworth, K., Dorsey, J., Edwards, P. M., Heard, D. E., Langford, B., Lee, J., Misztal, P. K., Whalley, L. K., and Pyle, J. A.: A global model study of the impact of land-use change in Borneo on atmospheric composition, Atmos. Chem. Phys., 13, 9183-9194, doi:10.5194/acp-13-91832013, 2013.

WHO: Air Quality Guidelines for Europe, Tech. rep., World Health Organization, Copenhagen, Denmark, 2000.

Wiedinmyer, C., Tie, X., Guenther, A., Neilson, R., and Granier, C.: Future changes in biogenic isoprene emissions: how might they affect regional and global atmospheric chemistry?, Earth Interact., 10, 1-19, 2006.

Wu, S., Mickley, L. J., Jacob, D. J., Logan, J. A., Yantosca, R. M., and Rind, D.: Why are there large differences between models in global budgets of tropospheric ozone?, J. Geophys. Res., 112, D05302, doi:10.1029/2006JD007801, 2007.

Wu, S., Mickley, L. J., Kaplan, J. O., and Jacob, D. J.: Impacts of changes in land use and land cover on atmospheric chemistry and air quality over the 21 st century, Atmos. Chem. Phys., 12, 15971609, doi:10.5194/acp-12-1597-2012, 2012.

Yienger, J. and Levy, H.: Empirical-model of global soil-biogenic $\mathrm{NO}_{\mathrm{x}}$ emissions, J. Geophys. Res., 100, 11447-11464, 1995.

Young, P. J., Arneth, A., Schurgers, G., Zeng, G., and Pyle, J. A.: The $\mathrm{CO}_{2}$ inhibition of terrestrial isoprene emission significantly affects future ozone projections, Atmos. Chem. Phys., 9, 27932803, doi:10.5194/acp-9-2793-2009, 2009.

Young, P. J., Archibald, A. T., Bowman, K. W., Lamarque, J.-F., Naik, V., Stevenson, D. S., Tilmes, S., Voulgarakis, A., Wild, O., Bergmann, D., Cameron-Smith, P., Cionni, I., Collins, W. J., Dalsøren, S. B., Doherty, R. M., Eyring, V., Faluvegi, G., Horowitz, L. W., Josse, B., Lee, Y. H., MacKenzie, I. A., Nagashima, T., Plummer, D. A., Righi, M., Rumbold, S. T., Skeie, R. B., Shindell, D. T., Strode, S. A., Sudo, K., Szopa, S., and Zeng, G.: Pre-industrial to end 21 st century projections of tropospheric ozone from the Atmospheric Chemistry and Climate Model Intercomparison Project (ACCMIP), Atmos. Chem. Phys., 13, 2063-2090, doi:10.5194/acp-13-2063-2013, 2013.

Zeng, G., Pyle, J. A., and Young, P. J.: Impact of climate change on tropospheric ozone and its global budgets, Atmos. Chem. Phys., 8, 369-387, doi:10.5194/acp-8-369-2008, 2008. 